\title{
Environmental
} Monitoring

Cite this: J. Environ. Monit., 2011, 13, 563

wWw.rsc.org/jem

PAPER

\section{Toxic and essential elements in blood from delivering women in selected areas of São Paulo State, Brazil}

\author{
Cibele V. C. Rudge, ${ }^{* a b}$ Iracema M. P. Calderon, ${ }^{a}$ Marilza V. C. Rudge, ${ }^{a}$ Gustavo Volpato, ${ }^{a}$ João L. P. Silva, ${ }^{c}$ \\ Geraldo Duarte, ${ }^{d}$ Corintio M. Neto, ${ }^{e}$ Nelson Sass,${ }^{f g}$ Rosiane Mattar, ${ }^{g}$ Halina B. Röllin, ${ }^{h i}$ Yngvar Thomassen ${ }^{j}$ \\ and Jon Ø. Odland ${ }^{b}$
}

Received 14th October 2010, Accepted 11th November 2010

DOI: 10.1039/c0em00570c

This study was designed to evaluate the degree of environmental contamination and possible exposure of pregnant women to toxic elements in seven selected areas of São Paulo State, Brazil. The overall median concentration of Mo in maternal blood was $0.53 \mu \mathrm{g} \mathrm{L}^{-1}$, highly significant differences found between sites $(\mathrm{p}<0.0001)$. Cd was found to be low overall $-0.09 \mu \mathrm{g} \mathrm{L}^{-1}\left(0.01-0.58 \mu \mathrm{g} \mathrm{L}^{-1}\right)-$ with mothers from the Coastal and Rural 1 sites having the highest levels $(\mathrm{p}<0.016)$.

Median $\mathrm{Hg}$ concentration was $0.60 \mu \mathrm{g} \mathrm{L}^{-1}\left(0.06 \mu \mathrm{g} \mathrm{L}^{-1}-4.35 \mu \mathrm{g} \mathrm{L}^{-1}\right)$; median Pb level was $16.2 \mu \mathrm{g} \mathrm{L}^{-1}$ (3.5-57.7 $\left.\mathrm{g} \mathrm{L} \mathrm{L}^{-1}\right)$ and no differences between sites were observed for both metals. Median Mn level was $16.7 \mu \mathrm{g} \mathrm{L}^{-1}\left(7.0-39.7 \mu \mathrm{g} \mathrm{L}^{-1}\right)$, being highest in Urban 2 site $(\mathrm{p}<0.016)$. Concentrations of maternal Co were found to range between $0.06 \mu \mathrm{g} \mathrm{L}^{-1}$ and $1.1 \mu \mathrm{g} \mathrm{L}^{-1}$ (median $0.25 \mu \mathrm{g} \mathrm{L}^{-1}$ ) and As level was $0.60 \mu \mathrm{g}$ $\mathrm{L}^{-1}\left(0.10-3.8 \mu \mathrm{g} \mathrm{L}^{-1}\right)$ overall, with no statistical significance between sites for Co and As. Median Se concentrations were found to be $64 \mu \mathrm{g} \mathrm{L}^{-1}\left(36-233 \mu \mathrm{g} \mathrm{L}^{-1}\right)$, with the highest median levels found in Urban 3 site; site differences were statistically significant $(\mathrm{p}<0.0001)$. Correlation for each element (between paired maternal and cord blood) was measured only in Rural site 1; significant correlation was shown for $\mathrm{Hg}, \mathrm{Pb}, \mathrm{Mn}$ and $\mathrm{Co}(\mathrm{p}<0.05)$. These findings may be interpreted as indicating low environmental contamination in São Paulo State, Brazil. These findings could also indicate that pregnant women have little or no contact with pollutants, possibly due to awareness campaigns carried out by public health practitioners.

\author{
${ }^{a}$ University Estadual Paulista, UNESP, R. General Telles, 1396. Botucatu, \\ SP, Brazil 18602-120. E-mail: cirudge@yahoo.com.br; Fax: +55 14 3882- \\ 2004; Tel: +55 $143882-2004$ \\ ${ }^{b}$ Institute of Community Medicine, University of Tromsø, Tromsø, Norway \\ ${ }^{c}$ University de Campinas, UNICAMP, Brazil \\ ${ }^{d}$ University São Paulo, USP-Ribeirão Preto, Brazil \\ ${ }^{e}$ Hospital and Maternity Leonor Mendes de Barros, São Paulo, Brazil \\ ${ }^{f}$ Maternity Vila Nova Cachoeirinha, São Paulo, Brazil \\ ${ }^{g}$ University Federal of São Paulo, UNIFESP, Brazil \\ ${ }^{h}$ South African Medical Research Council, Johannesburg, South Africa \\ ${ }^{i}$ School of Health Systems \& Public Health, University of Pretoria, \\ Pretoria, South Africa \\ ${ }^{j}$ National Institute for Occupational Health, Oslo, Norway
}

\section{Introduction}

Human exposures to toxic metals present in the living environment are receiving increased attention, raising public awareness that questions the sources and possible health effects of such exposures.

Exposures to toxic metals such as lead, cadmium, mercury and arsenic are the most threatening to human health. ${ }^{1,2}$ Although adverse health effects of these metals are well understood, exposures are continuing and even increasing in some parts of the world, especially in less developed countries. Due to stringent control measures, recent data indicate that emissions of these metals have declined in most of the developed countries, but due

\section{Environmental impact}

Contaminants and human reproductive health in Latin America is a new and important scientific field. The climate change issue adds more importance to accessing baseline information, as a tool for follow up studies at a later stage. Measuring the concentrations of toxic and essential elements in maternal blood during pregnancy gives an indication of the intra-uterine levels, as well as an indication of the potential risk to the developing foetus and young child. These findings may be interpreted as indicating low environmental contamination in São Paulo State in Brazil. 
to their chemical stability, these elements can persist in the environment for many years, even after cessation of the main sources of contamination. As exposures to metals are cumulative over the human lifetime, exposures to toxic elements are of concern to all age groups, but particularly to susceptible populations. These include pregnant women and neonates, children, the elderly, and individuals in poor health, those who are malnourished and socioeconomically disadvantaged. The most critical risk to health occurs from exposure in the early stages of life (prenatal and in utero), followed by adolescence and adulthood.

A number of ongoing studies have evaluated and characterised exposure levels and associated health outcomes in populations residing in different geographical regions. For example, lead has become a permanent source of environmental exposure for humans, and a number of current studies are assessing lead status in children. ${ }^{3,4}$

Lead and other persistent toxic metals can severely affect young children residing in the contaminated areas because of children's natural tendency of hand-to-mouth activity, their high rates of inhalation, ingestion and gastrointestinal absorption for their size, as well as their increased susceptibility to the health effects of toxic exposures. ${ }^{5}$ In children, lead blood levels of below $10 \mu \mathrm{g} / \mathrm{dL}$ have been considered acceptable to date; interventions are applied only when levels exceed this value. However, recent data indicate that there is no safe level of lead in blood and evidence is emerging that some genetic and environmental factors may render certain children more vulnerable to lead toxicity. ${ }^{1,3,6}$

Another concern is the ability of some toxic metals to disperse from the contamination sources and travel long distances across the globe. A good example is mercury, which can change into more toxic chemical forms and biomagnify in the food chain. Studies performed in Canada found elevated levels of methyl mercury not only in indigenous Dene and Inuit populations, but also in the general population residing in other areas of Canada. ${ }^{7}$

Apart from contaminating the food chain, elevated levels of metals have been detected in human fluids such as breast milk, in populations residing in different areas within the polar region, far removed from the actual sources of contamination. ${ }^{\mathbf{8} 9}$

Numerous investigations are ongoing in the northern hemisphere but to date very little is known about metal contamination in the southern hemisphere.

Recent literature reviews of the studies performed in Brazil show that lead, mercury and cadmium have been studied mostly as related to exposures during formal and informal occupational activities. Although mining of lead ceased in Brazil in 1995 and leaded gasoline was phased out in the 1980s (its use is now completely discontinued), environmental lead contamination is still of concern for public health. ${ }^{10}$

A number of environmental assessments have detected the presence of toxic metals in the region of Ribeira River and its contributory rivers in São Paulo State. ${ }^{11}$ There is also evidence of elevated blood lead levels in children residing in previous lead mining areas of Brazil. In 2002, a study by Paoliello et al. assessed the levels of blood lead in 295 children aged 7-14 years, residing in the Upper Ribeira de Iguape River Valley in São Paulo State (an area where mining and refining of lead was discontinued), and found that $59 \%$ of children had blood lead levels equal to or above $10 \mu \mathrm{g} \mathrm{dL}^{-1}$, with $12.8 \%$ of children having blood lead levels above $20 \mu \mathrm{g} \mathrm{dL}^{-1}$. A similar study was performed on 624 children aged $0-12$ years, residing about 1000 $\mathrm{m}$ from an active secondary smelting lead recycling plant in the Municipality of Bauru, also situated in the State of São Paulo. The mean blood lead levels in this group were found to be $9.28 \mu \mathrm{g}$ $\mathrm{dL}^{-1}$, with $36 \%$ of children exceeding the USA lead action levels of $10 \mu \mathrm{g} \mathrm{dL}^{-1}$. $^{2}$

Furthermore, in Santo Amaro da Purificaçao in the State of Bahia, Brazilian researchers also detected high levels of lead and cadmium. Associated toxic effects of exposure to these heavy metals were found in children and adults living in close proximity to a primary lead refinery. ${ }^{13-15}$ These findings are similar to those published in international studies. ${ }^{\mathbf{1 6}}$

The upper limit reference value for blood lead levels in occupationally exposed workers was introduced in Brazil in 2002; however, no reference values exist for the general population. ${ }^{15}$

Another metal of concern worldwide is mercury, which is listed among the most toxic substances in industrialized countries. One third of mercury emissions originate from natural sources and the other two thirds from anthropogenic activities. As in other countries with rich gold deposits, artisanal and small-scale gold mining activities using mercury, combined with rudimentary technology, are widespread in the Brazilian Amazon Riverine, impacting not only the ecology but also the health of miners, their families and other inhabitants of the communities. It is reported that young children of fish-eating populations of the Amazon Basin are exposed to maternal methyl mercury $(\mathrm{MeHg})$ during pregnancy via placental transfer, and via breast milk after birth. ${ }^{17-20}$

In this context, the increase in the risk of neurodevelopmental disorders (NDD) has been strongly suggested to be associated with $\mathrm{MeHg}$ present in fish from the Amazonian rivers. The vulnerability of the developing human brain in utero remains the most important window for the harmful effects of mercury compounds. $^{21}$

It is thought that in some areas of Brazil dietary intake of fish and seafood products is the main source of $\mathrm{MeHg}$ exposure in the general population. This form of mercury is easily absorbed by the gastrointestinal tract and distributed throughout the body within 3-4 days. It is estimated that 5\% of dietary $\mathrm{MeHg}$ is found in the blood and $10 \%$ in the brain, with the half-life ranging between 45 and 70 days. ${ }^{22}$

In Brazil and elsewhere, young children can also be iatrogenically exposed to other forms of organic $\mathrm{Hg}$, such as ethyl mercury (EtHg), when immunized with thimerosal-containing vaccines. $^{23}$

These and other similar studies suggest the existence of environmental metal contamination in various parts of Brazil; it is expected that the intensity of the metal contamination will differ between locations within Brazil, as it is such a vast country in size.

To define possible toxic impacts of pollutants in different stages of human development, many recent studies have been performed on women in different stages of pregnancy and at delivery. The embryonic and foetal developmental stages are the most vulnerable for the detrimental health effects of contaminants. Measuring the concentrations of metals and elements in maternal blood during pregnancy gives a good indication of the intra-uterine levels, as well as an indication of the potential risk to the developing foetus and young child. Of particular concern 
are long-term, subtle effects that may influence reproductive health and pregnancy outcomes, thus reducing defence against diseases and affecting children's mental development, or increasing the risk of cancer. .2,24,25 $^{2}$

This study was designed to evaluate the degree of environmental contamination and possible exposure of pregnant women to toxic substances in the selected areas of São Paulo State, Brazil, so as to inform reproductive, paediatric, public and environmental health practices.

This survey was carried out under the auspices of Arctic Monitoring and Assessment Programme (AMAP), by the São Paulo State University (UNESP) and the University of Tromsø, Norway during 2006-2009. Although both metals and organic persistent pollutants were measured, this paper reports on the levels of molybdenum (Mo), cadmium (Cd), mercury ( $\mathrm{Hg})$, lead $(\mathrm{Pb})$, manganese $(\mathrm{Mn})$, cobalt $(\mathrm{Co})$, copper $(\mathrm{Cu})$, zinc $(\mathrm{Zn})$, arsenic (As) and selenium (Se) found in the maternal whole blood of randomly selected delivering women in seven regions of São Paulo State, Brazil. Additional or confounding factors related to the socioeconomic, health status from hospital records, life style and birth outcomes of participants are also discussed. The results for the organic persistent pollutants measured in maternal whole blood will be reported separately.

\section{Materials and methods}

\section{Study sites and population}

São Paulo State is the most developed state in Brazil with an area of $248808 \mathrm{~km}^{2}$, a population of approximately 40 million inhabitants, and a population density of $160.5 \mathrm{hab} \mathrm{km}^{-2}$. This cross-sectional study took place in seven sites of São Paulo State, situated in the south-eastern region of Brazil. The following locations were selected for the study: two rural sites, located inland approximately $230 \mathrm{~km}$ from São Paulo city (Botucatu and Ribeirão Preto), one industrial site (Campinas), one coastal site (Santos) and three metropolitan urban sites (University Federal of São Paulo (UNIFESP), Vila Nova Cachoeirinha and Hospital and Maternity Leonor Mendes de Barros, HMMLMB) (Fig. 1).
The subjects of this study were in total 155 delivering women from seven selected sites. Enrolment criteria for this project included women who were admitted to the delivery rooms at seven maternity hospitals during 2007 and 2008 and had resided in the specific study site for at least 1 year prior to the pregnancy. Women who volunteered to participate in the study signed an informed consent form and agreed to donate blood, answer a socio-economic questionnaire and allow access to their health and post-delivery records. Standardized data collection forms, used in prior studies, were adapted for the Brazilian population, translated and pre-tested before commencement of the survey. ${ }^{26}$ Participation in the study was voluntary, confidentiality was assured and participants were informed that they could withdraw from the study at any time.

\section{Data collection}

The data and blood collection from the volunteers was conducted in the selected maternity hospitals. Demographic data, life style, diet, proximity of any source of environmental contamination, occupational activity, smoking habits, alcohol consumption, and leisure activities were obtained from each participant and health status data were obtained from the existing hospital files of each participant. Newborns were clinically examined with special attention to vitality, perinatal reflexes, maturity, and congenital malformations; weight, length, head circumference, and Apgar scores, and these data were recorded.

\section{Sampling procedures}

For the analysis, maternal blood was collected within one day post-partum. From each mother, approximately $10 \mathrm{ml}$ of blood was drawn by venous puncture into Vacutainer tubes (trace metal free, heparinized tubes) using the sterile Vacutainer disposable system. Umbilical cord blood was collected at delivery only from the participants from Botucatu rural site. These were stored at $-4{ }^{\circ} \mathrm{C}$ until all samples were shipped in a frozen state to the University of Tromsø, in Norway, for analysis. Measurements of metal content in whole blood were
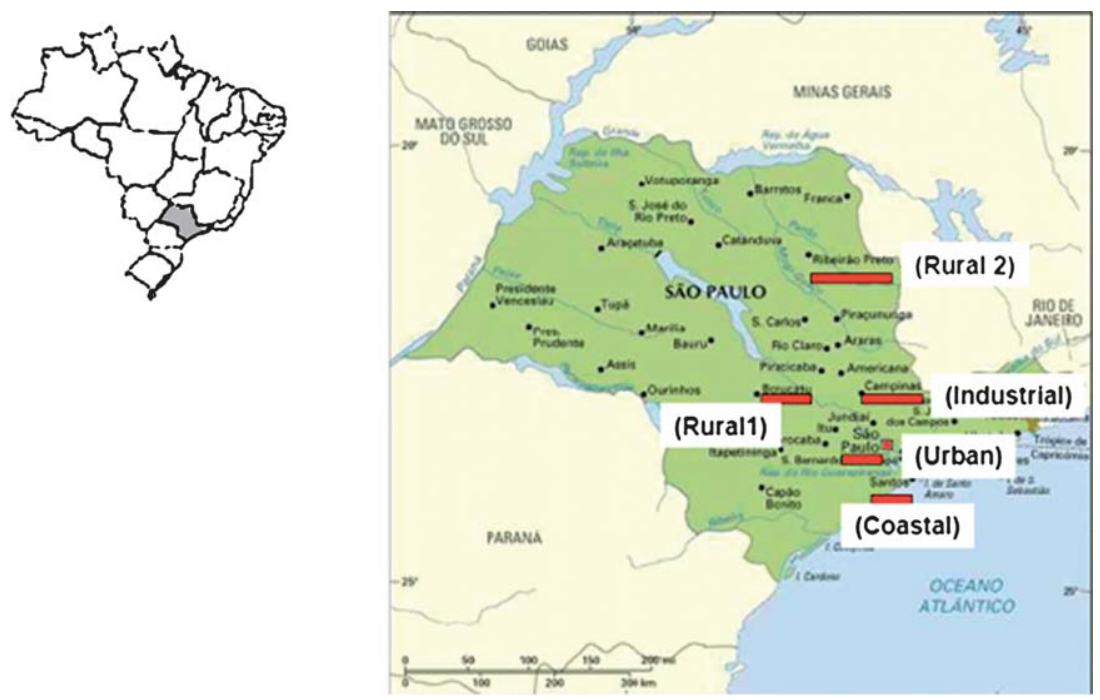

Fig. 1 Geographical locations of study sites within Brazil (all three urban sites are located in São Paulo city). 
performed by the National Institute for Occupational Health (NIOH), Oslo, Norway.

\section{Analytical methods}

Samples of maternal and cord whole blood were analysed for levels of $\mathrm{Mo}, \mathrm{Cd}, \mathrm{Hg}, \mathrm{Pb}, \mathrm{Mn}, \mathrm{Co}, \mathrm{Cu}, \mathrm{Zn}, \mathrm{As}$, and Se. Elements such as $\mathrm{Mn}, \mathrm{Cu}, \mathrm{Zn}, \mathrm{Mo}$ and Se are considered as essential trace elements, but are known to be toxic at elevated levels and detrimental to health if deficient. Chemical analyses were performed using the inductively coupled plasma-mass spectrometry (ICP-MS) technique. The required contamination elimination procedures and validation of results (the use of certified standards) were applied throughout the analyses.

\section{Sample preparation}

For the measurements of elements in whole blood, $1.5 \mathrm{~mL}$ of $65 \%$ ultrapure nitric acid (Chemscan Ltd., Elverum, Norway) was added to $1 \mathrm{~mL}$ of whole blood in a polypropylene digestion tube. The mixture was digested by heating the tube at $95^{\circ} \mathrm{C}$ for $1 \mathrm{~h}$. The acid homogenization procedure using nitric acid was performed in covered tubes at ambient pressure, and is a well accepted and verified procedure for whole blood, with no losses of e.g. Se or $\mathrm{Hg}$. These procedures have been carefully studied and are used extensively at $\mathrm{NIOH}$, as well as by many other international laboratories.

The digest was cooled to room temperature and $200 \mu \mathrm{L}$ of an internal standard solution containing ${ }^{72} \mathrm{Ge}$ for ${ }^{75} \mathrm{As}$ and ${ }^{77,78,82} \mathrm{Se}$, ${ }^{115} \mathrm{In}$ for ${ }^{114} \mathrm{Cd}$, ${ }^{204} \mathrm{Tl}$ for ${ }^{206,207,208} \mathrm{~Pb}$ and ${ }^{200,201,202} \mathrm{Hg},{ }^{60} \mathrm{Ni}$ for ${ }^{55} \mathrm{Mn}$, ${ }^{59} \mathrm{Co},{ }^{63,65} \mathrm{Cu}$ and ${ }^{64,66,68} \mathrm{Zn}$ was added and diluted to a final volume of $10 \mathrm{~mL}$ with ultrapure water.

\section{Instrumental measurements}

The digested blood was analysed by using an Element 2 mass spectrometer (Thermo Electron, Bremen, Germany) calibrated with the whole blood matched standard solutions. The instrument was programmed to determine $\mathrm{Cd}$ by use of the ${ }^{114} \mathrm{Cd}^{+}$ion with automatic mass correction caused by the ${ }^{114} \mathrm{Sn}^{+}$ionic interference. Since the Mo concentration in whole blood is around $1 \mathrm{ng} \mathrm{mL}^{-1}$ or lower, any mass interference at ${ }^{114} \mathrm{Cd}^{+}$from the ${ }^{98} \mathrm{Moo}^{16} \mathrm{O}^{+}$was not considered to contribute to the overall signal. The following mass resolutions were used; low for $\mathrm{Cd}, \mathrm{Hg}$, $\mathrm{Pb}$; medium for $\mathrm{Mn}, \mathrm{Cu}, \mathrm{Zn}$; and high for $\mathrm{As}$ and $\mathrm{Se}$. The detection limits (three times the standard deviation of all blank samples) for metals in whole blood were as follows: As: $0.09 \mu \mathrm{g}$ $\mathrm{L}^{-1}$, Cd: $0.01 \mu \mathrm{g} \mathrm{L}^{-1}$, Co: $0.07 \mu \mathrm{g} \mathrm{L}{ }^{-1}$, Cu: $1 \mu \mathrm{g} \mathrm{L}^{-1}, \mathrm{Hg}: 0,1 \mu \mathrm{g}$ $\mathrm{L}^{-1}$, Mn: $0.3 \mu \mathrm{g} \mathrm{L}^{-1}, \mathrm{~Pb}: 0.1 \mu \mathrm{g} \mathrm{L}{ }^{-1}$, Se: $1 \mu \mathrm{g} \mathrm{L}^{-1}, \mathrm{Zn}: 20 \mu \mathrm{g} \mathrm{L}^{-1}$. One aliquot of each blood sample was analysed in triplicate. Seronorm $^{\mathrm{TM}}$ Trace Elements (Sero Ltd., Billingstad, Norway) human whole blood quality control materials were used for quality assurance of all element measurements; after every ten blood samples analysed, a quality control sample at two different concentration levels was also analysed.

The NIOH laboratory in Oslo, Norway participates in the Wadsworth Center-New York State Department of Health Proficiency (USA) trace element testing schemes for whole blood and urine, with consistently acceptable results and no indication of any systematic biases.

\section{Statistical analysis}

Statistical analyses were conducted using the statistical STATA package, version $10 .{ }^{27}$ The quantitative variables (median, range, first and third quartiles) are presented. In cases where concentrations of metals were equal to or below the level of detection (LOD) of the instrument, the concentrations were set at $0.5 \times$ LOD, for statistical purposes. Comparisons between sites were performed using Kruskal-Wallis and Dunn tests for multiple comparisons. The significance $\mathrm{p}$ value was set at 0.05 . Correlation between the quantitative variables was evaluated by means of Spearman's correlation.

The Spearman's correlation coefficient model was used to evaluate the levels of selected elements between paired maternal and cord whole blood samples.

\section{Ethical considerations}

The present study was approved by the Brazilian National Research Ethical Council (CONEP-Brazil; protocol number 12388). The study subjects were women admitted for delivery at institutional hospitals in each of the seven study sites. Potential participants received plain-language information about the study and those who agreed to participate signed a written consent form, which stated that participation was voluntary, confidentiality was assured and participants could withdraw from the study at any time. Subjects were also informed that if results were cause for concern, they would be referred to an appropriate medical facility for further investigation. Ninety eight percent of potential study participants approached agreed to participate.

\section{Results}

Collection of blood from a total of 155 delivering women took place during 2007 and 2008, and the analytical measurements were completed at the end of 2009. In the results tables, study sites are referred to according to their characteristics, and presented in a particular order: Rural 1 (Botucatu); Rural 2 (Ribeirão Preto); São Paulo metropolis is divided into: Urban 1 (UNIFESP), Urban 2 (Vila Nova Cachoeirinha), Urban 3 (HMMLMB); Industrial (Campinas) and Coastal (Santos).

\section{Socio-economic, demographic and lifestyle characteristics}

Socio-economic, demographic and lifestyle characteristics of participants at each study site are summarised in Table 1. The subsets did not differ from the overall cohort in terms of demographic variables. The majority of participants were married or lived with their partners, owned their own homes (median 3 rooms/house) and reported a median monthly income of about US\$ 480 . The majority of subjects classified themselves as being from the Caucasian race. Less than half of the women were employed. The majority $(90 \%)$ of the participants reported themselves to be in a good state of health; the study subjects who reported being most satisfied with their living environment were from the industrial site. About $48 \%$ of participants reported that at least one person smoked at home. 
Table 1 Socio-demographic characteristics and life habits of participants by site

\begin{tabular}{|c|c|c|c|c|c|c|c|c|}
\hline Statistics & $\begin{array}{l}\text { Rural 1 } \\
(\mathrm{n}=36)\end{array}$ & $\begin{array}{l}\text { Rural } 2 \\
(\mathrm{n}=19)\end{array}$ & $\begin{array}{l}\text { Urban } 1 \\
(\mathrm{n}=20)\end{array}$ & $\begin{array}{l}\text { Urban } 2 \\
(\mathrm{n}=20)\end{array}$ & $\begin{array}{l}\text { Urban } 3 \\
(\mathrm{n}=20)\end{array}$ & $\begin{array}{l}\text { Industrial } \\
(\mathrm{n}=20)\end{array}$ & $\begin{array}{l}\text { Ocean } \\
(\mathrm{n}=20)\end{array}$ & $\begin{array}{l}\text { Total } \\
(\mathrm{n}=155)\end{array}$ \\
\hline Population group (\%) & $\mathrm{B}=11$ & $\mathrm{~B}=6$ & $\mathrm{~B}=10$ & $\mathrm{~B}=29$ & $\mathrm{~B}=15$ & $\mathrm{~B}=0$ & $\mathrm{~B}=10$ & $\mathrm{~B}=12$ \\
\hline $\mathrm{B}=$ Black, $\mathrm{C}=$ Coloured & $\mathrm{C}=31$ & $\mathrm{C}=26$ & $C=45$ & $\mathrm{C}=33$ & $\mathrm{C}=15$ & $\mathrm{C}=15$ & $\mathrm{C}=20$ & $\mathrm{C}=26$ \\
\hline $\mathrm{W}=$ White & $\mathrm{W}=58$ & $\mathrm{~W}=68$ & $\mathrm{~W}=45$ & $\mathrm{~W}=38$ & $\mathrm{~W}=70$ & $\mathrm{~W}=85$ & $\mathrm{~W}=70$ & $\mathrm{~W}=62$ \\
\hline $\begin{array}{l}\text { Do you consider yourself healthy } \\
\text { (\% YES) }\end{array}$ & 81 & 100 & 65 & 90 & 95 & 100 & 90 & 89 \\
\hline $\begin{array}{l}\text { Marital status } \mathrm{M}=\text { married/living } \\
\text { together }(\%)\end{array}$ & 89 & 90 & 85 & 80 & 65 & 65 & 80 & 79 \\
\hline Home ownership (\%) & 63 & 52 & 60 & 62 & 75 & 75 & 65 & 65 \\
\hline Rooms & 3.2 & 3.0 & 2.7 & 2.1 & 2.1 & 2.8 & 2.5 & 2.7 \\
\hline Income/monthly-median (US\$) & 388 & 388 & 555 & 600 & 388 & 417 & 611 & 478 \\
\hline Employed \% & 46 & 16 & 40 & 40 & 20 & 30 & 50 & 35 \\
\hline $\begin{array}{l}\text { Somebody smoking in household } \\
(\%)\end{array}$ & 56 & 53 & 60 & 57 & 40 & 25 & 30 & 46 \\
\hline $\begin{array}{l}\text { Environmental pollution in } \\
\text { neighbourhood? (\%yes) }\end{array}$ & 33 & 74 & 45 & 52 & 55 & 25 & 55 & 48 \\
\hline
\end{tabular}

\section{Maternal age, weight, height, parity and neonatal outcomes by site}

Table 2 shows maternal age, weight, height, parity and neonatal outcomes by site. The mean maternal age of all delivering women was 26 years; the youngest was 14 years old and the oldest was 43 years old. The parity ranged from 1 to 9 with a median of 2 . Overall, $35.6 \%$ of deliveries were by Caesarean section. The mean maternal weight on the last prenatal care visit was $74.5 \mathrm{~kg}$, varying from $45 \mathrm{~kg}$ to $114 \mathrm{~kg}$, and the mean maternal height was $1.60 \mathrm{~m}$, ranging from $1.45 \mathrm{~m}$ to $1.73 \mathrm{~m}$.

Overall birth weight for newborns ranged between $995 \mathrm{~g}$ and $4460 \mathrm{~g}$, and length from $29 \mathrm{~cm}$ to $58 \mathrm{~cm}$. The mean gestational age at delivery was 38.2 weeks, varying from 28 to 42 weeks. Deliveries at all sites took place in tertiary hospitals with the majority of patients presenting with high risk pregnancies.
Therefore, the low birth weight and prematurity can be assumed to be related to different pathologies during pregnancy. Gender ratio differed between sites, ranging from 31.5 to $71 \%$ frequency for girls. There were differences between sites, however, the overall frequency showed no statistical differences due to small sample size.

\section{Maternal blood levels of $\mathrm{Mo}, \mathrm{Cd}, \mathrm{Hg}, \mathrm{Pb}, \mathrm{Mn}, \mathrm{Co}, \mathrm{Cu}, \mathrm{Zn}, \mathrm{As}$ and Se}

Concentrations of the different elements in the maternal blood, by site, are summarised in Table 3 . The median concentration of Mo differed between sites with the Urban 1 and Urban 2 sites having the highest concentration $\left(0.75 \mu \mathrm{g} \mathrm{L}^{-1}\right)$ and the Rural 2 site the lowest level $\left(0.39 \mu \mathrm{g} \mathrm{L}^{-1}\right)$; with differences being highly significant between sites $(\mathrm{p}<0.0001)$.

Table 2 Maternal age, weight, height, parity and birth outcomes by site

\begin{tabular}{|c|c|c|c|c|c|c|c|c|}
\hline Statistics & $\begin{array}{l}\text { Rural 1 } \\
(\mathrm{n}=36)\end{array}$ & $\begin{array}{l}\text { Rural } 2 \\
(\mathrm{n}=19)\end{array}$ & $\begin{array}{l}\text { Urban } 1 \\
(\mathrm{n}=20)\end{array}$ & $\begin{array}{l}\text { Urban } 2 \\
(\mathrm{n}=20)\end{array}$ & $\begin{array}{l}\text { Urban } 3 \\
(\mathrm{n}=20\end{array}$ & $\begin{array}{l}\text { Industrial } \\
(\mathrm{n}=20)\end{array}$ & $\begin{array}{l}\text { Ocean } \\
(\mathrm{n}=20)\end{array}$ & $\begin{array}{l}\text { All } \\
\mathrm{n}=155\end{array}$ \\
\hline \multicolumn{9}{|l|}{ Maternal age } \\
\hline mean (SD) & $\begin{array}{l}29.1 \\
6.4\end{array}$ & $\begin{array}{l}24.6 \\
6.8\end{array}$ & $\begin{array}{l}29.4 \\
7.6\end{array}$ & $\begin{array}{l}22.9 \\
4.5\end{array}$ & $\begin{array}{l}25.4 \\
6.3\end{array}$ & $\begin{array}{l}24 \\
6.5\end{array}$ & $\begin{array}{l}26.1 \\
6.2\end{array}$ & $\begin{array}{l}26 \\
5.4\end{array}$ \\
\hline \multicolumn{9}{|l|}{ Maternal weight $(\mathrm{kg})$} \\
\hline Mean & 77.3 & 75.4 & 72.6 & 72.8 & 71.8 & 77.5 & 73.9 & 74.5 \\
\hline $\begin{array}{l}\text { SD } \\
\text { Maternal height (m) }\end{array}$ & 13.6 & \multicolumn{6}{|c|}{ Maternal height (m) } & 15.8 \\
\hline Mean & 1.60 & 1.60 & 1.62 & 1.60 & 1.63 & 1.58 & 1.62 & 1.60 \\
\hline SD & 0.07 & 0.08 & 0.06 & 0.07 & 0.07 & 0.11 & 0.08 & 0.08 \\
\hline Parity median (range) & $2(1-9)$ & $2(1-8)$ & $3(2-4)$ & $2(1-3)$ & $2(1-6)$ & $2(1-3)$ & $2(1-4)$ & $2(1-5)$ \\
\hline \multicolumn{9}{|l|}{ Birth weight $(\mathrm{g})$} \\
\hline mean & 3021 & 2735 & 3138 & 3259 & 3200 & 2928 & 3069 & 3050 \\
\hline SD & 469 & 740 & 683 & 397 & 339 & 567 & 505 & 529 \\
\hline \multicolumn{9}{|l|}{ Birth length (cm) } \\
\hline Mean & 47 & 47.4 & 47.5 & 48.0 & 48.8 & 47.4 & 47.5 & 47.7 \\
\hline SD & 5.0 & 3.5 & 3.0 & 2.8 & 2.1 & 4.8 & 2.6 & 3.4 \\
\hline \multicolumn{9}{|l|}{ Head circumference $(\mathrm{cm})$} \\
\hline Mean & 35.0 & 33.9 & 34.2 & 35.1 & 34.3 & 34.9 & 34.5 & 34.6 \\
\hline SD & 3.6 & 2.3 & 1.6 & 1.4 & 1.3 & 2.8 & 1.6 & 2.4 \\
\hline \multicolumn{9}{|l|}{ Gestational age (w) } \\
\hline mean & 38.3 & 37.0 & 38.0 & 39.2 & 38.6 & 37.8 & 38.2 & 38.2 \\
\hline SD & 2.1 & 3.9 & 1.6 & 1.4 & 1.5 & 2.2 & 2.1 & 2.1 \\
\hline Gender: girls (\%) & 36.1 & 31.6 & 55 & 71 & 31.5 & 65 & 60 & 50 \\
\hline Caesarean section (\%) & 39 & 32 & 50 & 25 & 10 & 50 & 45 & 36 \\
\hline
\end{tabular}


The median concentration of $\mathrm{Cd}$ in maternal blood was found to be low overall, ranging between 0.01 and $0.58 \mu \mathrm{g} \mathrm{L}^{-1}$, with mothers from Industrial site having the lowest $\mathrm{Cd}$ levels, and mothers from Coastal and Rural 1 sites having the highest levels (median $0.1 \mu \mathrm{g} \mathrm{L}^{-1}$ ) with differences reaching statistical significance of $\mathrm{p}<0.016$ between sites.

The overall median blood $\mathrm{Hg}$ concentrations were found to be $0.60 \mu \mathrm{g} \mathrm{L}^{-1}$ (range $0.06-4.35 \mu \mathrm{g} \mathrm{L}^{-1}$ ). Urban 2 and Urban 3 sites were found to have the lowest median concentrations of $\mathrm{Hg}$ $\left(0.50 \mu \mathrm{g} \mathrm{L}^{-1}\right.$ in both) and Urban 1 and Coastal sites having the highest median concentrations of $\mathrm{Hg}, 0.72 \mu \mathrm{g} \mathrm{\textrm {L } ^ { - 1 }}$ and $0.73 \mu \mathrm{g} \mathrm{L}^{-1}$ respectively, without reaching statistical significance between sites.

The median concentrations of $\mathrm{Pb}$ levels were $16.2 \mu \mathrm{g} \mathrm{L}^{-1}$ and found to be similar in all sites with no statistical differences. The Mn levels were found to be highest in Urban 2 site with the median concentration reaching $20.3 \mu \mathrm{g} \mathrm{L}^{-1}$ and lowest in Urban $1\left(13.55 \mu \mathrm{g} \mathrm{L}^{-1}\right)$ reaching statistical significance of $\mathrm{p}<0.016$ between sites.

Concentrations of maternal Co were found to range between $0.06 \mu \mathrm{g} \mathrm{L}^{-1}$ and $1.1 \mu \mathrm{g} \mathrm{L}^{-1}$ overall (median $0.25 \mu \mathrm{g} \mathrm{L}^{-1}$ ), with no significant differences between study sites. The median As levels were found to be $0.60 \mu \mathrm{g} \mathrm{L}^{-1}$ overall with no statistical significance between sites.

The essential metal $\mathrm{Cu}$ levels in maternal whole blood were found to be highest in Rural 2 and Urban $2\left(1800 \mu \mathrm{g} \mathrm{L}^{-1}\right)$ and reaching statistical significance of $\mathrm{p}<0.038$ overall. The overall median concentration of $\mathrm{Zn}$ was found to be $6420 \mu \mathrm{g} \mathrm{L}^{-1}$, ranging between $2850 \mu \mathrm{g} \mathrm{L}^{-1}$ and $10100 \mu \mathrm{g} \mathrm{L}^{-1}$ with the highest median levels of $\mathrm{Zn}\left(7165 \mu \mathrm{g} \mathrm{L}^{-1}\right)$ measured in Rural 1 site; highly significant differences between sites were observed $(p<0.0001)$. Overall, median Se concentrations were found to be $64 \mu \mathrm{g} \mathrm{L}^{-1}$, ranging between $36 \mu \mathrm{g} \mathrm{L}^{-1}$ and $233 \mu \mathrm{g} \mathrm{L}^{-1}$, with highest median levels found in the Urban 3 site $\left(73 \mu \mathrm{g} \mathrm{L}^{-1}\right)$ which was highly significantly raised if compared with all other sites $(p<0.0001)$.

\section{Umbilical cord blood levels of $\mathrm{Cd}, \mathrm{Hg}, \mathrm{Pb}, \mathrm{Mn}, \mathrm{Co}, \mathrm{Cu}, \mathrm{Zn}, \mathrm{As}$, Se and Mo in Rural 1 site (Botucatu)}

The paired maternal and umbilical cord blood concentration, only for Rural 1 site, are summarised in Table 4. All elements measured were detected in umbilical cord blood. Median cord blood levels of $\mathrm{Cd}$ were found to be low $\left(0.01 \mu \mathrm{g} \mathrm{L}^{-1}\right)$, ranging between $0.01 \mu \mathrm{g} \mathrm{L}^{-1}$ and $0.1 \mu \mathrm{g} \mathrm{L}^{-1}$. The median levels of $\mathrm{Hg}$ in cord blood were found to reach $1.07 \mu \mathrm{g} \mathrm{\textrm {L } ^ { - 1 }}$, ranging between $0.44 \mu \mathrm{g} \mathrm{L}^{-1}$ and $8.26 \mu \mathrm{g} \mathrm{L}^{-1}$. The median levels of $\mathrm{Pb}$ were $12.9 \mu \mathrm{g}$ $\mathrm{L}^{-1}$, (range $7.5 \mu \mathrm{g} \mathrm{L}^{-1}-26.4 \mu \mathrm{g} \mathrm{L}^{-1}$ ). Levels of $\mathrm{Mn}$ in cord blood ranged from $22.5 \mu \mathrm{g} \mathrm{L}^{-1}$ to $66.1 \mu \mathrm{g} \mathrm{L}^{-1}$ with a median value of $36.6 \mu \mathrm{g} \mathrm{L}^{-1}$. Median levels of Co, Mo and Se were very similar to the paired maternal concentrations of these elements. Median As levels were found to be $0.97 \mu \mathrm{g} \mathrm{L}^{-1}$ (range $0.44 \mu \mathrm{g} \mathrm{L}{ }^{-1}-4.5 \mu \mathrm{g}$

Table 3 Concentration of $\mathrm{Mo}, \mathrm{Cd}, \mathrm{Hg}, \mathrm{Pb}, \mathrm{Mn}, \mathrm{Co}, \mathrm{Cu}, \mathrm{Zn}, \mathrm{As}$, and $\mathrm{Se}$ in maternal blood $\left(\mu \mathrm{g} \mathrm{L}^{-1}\right)$ by site ${ }^{a}$

\begin{tabular}{|c|c|c|c|c|c|c|c|c|c|c|}
\hline $\begin{array}{l}\text { Elements } \\
\left(\mu \mathrm{g} \mathrm{L}^{-1}\right)\end{array}$ & Statistics & $\begin{array}{l}\text { All sites } \\
\mathrm{N}=155\end{array}$ & $\begin{array}{l}\text { Rural } 1 \\
\mathrm{~N}=36\end{array}$ & $\begin{array}{l}\text { Rural } 2 \\
\mathrm{~N}=19\end{array}$ & $\begin{array}{l}\text { Urban } 1 \\
\mathrm{~N}=20\end{array}$ & $\begin{array}{l}\text { Urban } 2 \\
\mathrm{~N}=20\end{array}$ & $\begin{array}{l}\text { Urban } 3 \\
\mathrm{~N}=19\end{array}$ & $\begin{array}{l}\text { Industrial } \\
\mathrm{N}=20\end{array}$ & $\begin{array}{l}\text { Ocean } \\
\mathrm{N}=20\end{array}$ & $\begin{array}{l}\mathrm{P} \\
\text { value }\end{array}$ \\
\hline \multirow[t]{3}{*}{$\mathrm{Mo}^{c}$} & Median & 0.53 & 0.48 & 0.39 & 0.76 & 0.74 & 0.48 & 0.51 & 0.59 & \multirow[t]{3}{*}{$0.0001^{c}$} \\
\hline & Range & $0.22-1.48$ & $0.22-1.23$ & $0.31-1.28$ & $0.41-1.48$ & $0.4-1.14$ & $0.31-1.03$ & $0.25-1.03$ & $0.28-1.02$ & \\
\hline & IQR & $0.43-0.76$ & $0.38-0.59$ & $0.35-0.50$ & $0.54-0.90$ & $0.57-0.88$ & $0.43-0.87$ & $0.43-0.78$ & $0.46-0.71$ & \\
\hline \multirow[t]{3}{*}{$\mathrm{Cd}^{b}$} & Median & 0.09 & 0.10 & 0.08 & 0.09 & 0.09 & 0.08 & 0.07 & 0.10 & \multirow[t]{3}{*}{$0.016^{b}$} \\
\hline & Range & $0.01-0.58$ & $0.01-0.58$ & $0.03-0.32$ & $0.05-0.56$ & $0.04-0.20$ & $0.04-0.39$ & $0.03-0.15$ & $0.04-0.25$ & \\
\hline & IQR & $0.07-0.13$ & $0.06-0.20$ & $0.07-0.12$ & $0.07-0.11$ & $0.08-0.14$ & $0.07-0.12$ & $0.05-0.07$ & $0.09-0.16$ & \\
\hline \multirow[t]{3}{*}{$\mathrm{Hg}$} & Median & 0.60 & 0.66 & 0.69 & 0.72 & 0.50 & 0.50 & 0.56 & 0.73 & \multirow[t]{3}{*}{0.409} \\
\hline & Range & $0.06-4.35$ & $0.06-4.35$ & $0.35-2.02$ & $0.24-1.72$ & $0.2-3.21$ & $0.19-1.68$ & $0.18-2.99$ & $0.2-3.02$ & \\
\hline & IQR & $0.38-0.97$ & $0.50-1.21$ & $0.37-0.88$ & $0.35-1.14$ & $0.29-0.9$ & $0.36-0.66$ & $0.46-0.88$ & $0.41-1.13$ & \\
\hline \multirow[t]{3}{*}{$\mathrm{Pb}$} & Median & 16.2 & 14.4 & 16.3 & 15.2 & 16.3 & 17.2 & 16.5 & 17.0 & \multirow[t]{3}{*}{0.534} \\
\hline & Range & $3.5-57.7$ & $3.5-57.7$ & $9.1-24$ & $8.6-31$ & $11-39.4$ & $7.3-38.9$ & $9.5-26.1$ & $8.4-35$ & \\
\hline & IRQ & $12.2-20.4$ & $11.2-21.7$ & $11.1-19.5$ & $11.3-17.0$ & $13.1-30.3$ & $14.1-21.4$ & $13.8-20.3$ & $12.0-20.9$ & \\
\hline \multirow[t]{3}{*}{$\mathrm{Mn}^{b}$} & Median & 16.7 & 19.2 & 16.7 & 13.6 & 20.3 & 18.4 & 14.1 & 16.0 & \multirow[t]{3}{*}{$0.016^{b}$} \\
\hline & Range & $7.0-39.7$ & $7.0-39.7$ & $8.6-28.8$ & $8.3-22.4$ & $9.6-29.4$ & $8.5-32.4$ & $7.4-34.2$ & $9.4-31.4$ & \\
\hline & IQR & $13.2-21.6$ & $11.9-24.7$ & $13.2-18.8$ & $12.4-17.1$ & $16.5-24.1$ & $13.5-24.8$ & $11.8-15.9$ & $14.1-24.6$ & \\
\hline \multirow[t]{3}{*}{ Co } & Median & 0.25 & 0.25 & 0.22 & 0.23 & 0.28 & 0.34 & 0.22 & 0.31 & \multirow[t]{3}{*}{0.685} \\
\hline & Range & $0.06-1.1$ & $0.09-1.1$ & $0.11-0.53$ & $0.12-0.58$ & $0.14-0.75$ & $0.06-0.72$ & $0.11-0.55$ & $0.09-0.51$ & \\
\hline & IQR & $0.17-0.40$ & $0.16-0.43$ & $0.18-0.29$ & $0.17-0.36$ & $0.22-0.46$ & $0.15-0.51$ & $0.18-0.30$ & $0.15-0.38$ & \\
\hline \multirow[t]{3}{*}{$\mathrm{Cu}^{b}$} & Median (SD) & 1735 & 1735 & 1800 & 1545 & 1800 & 1580 & 1750 & 1790 & \multirow[t]{3}{*}{$0.038^{b}$} \\
\hline & Range & $610-3070$ & $1260-2650$ & $\begin{array}{l}1280- \\
2200\end{array}$ & $\begin{array}{r}1280- \\
2640\end{array}$ & $\begin{array}{r}1450- \\
3070\end{array}$ & $610-2360$ & $\begin{array}{r}1200- \\
2170\end{array}$ & $\begin{array}{l}1290- \\
2380\end{array}$ & \\
\hline & IQR & $1540-1930$ & 1580-1980 & $\begin{array}{l}1580- \\
2040\end{array}$ & $\begin{array}{r}1395- \\
1895\end{array}$ & $\begin{array}{c}1680- \\
1955\end{array}$ & $\begin{array}{r}1380- \\
1740\end{array}$ & $\begin{array}{c}1550- \\
1930\end{array}$ & $\begin{array}{r}1635- \\
1900\end{array}$ & \\
\hline \multirow[t]{3}{*}{$\mathrm{Zn}^{c}$} & Median & 6420 & 7165 & 6300 & 5665 & 7135 & 6240 & 6140 & 6365 & \multirow[t]{3}{*}{$0.001^{c}$} \\
\hline & Range & $\begin{array}{l}2850- \\
10100\end{array}$ & $\begin{array}{l}3760- \\
10100\end{array}$ & $\begin{array}{r}4270- \\
7930\end{array}$ & $\begin{array}{r}2650- \\
8180\end{array}$ & $\begin{array}{l}5320- \\
9990\end{array}$ & $\begin{array}{r}4100- \\
7630\end{array}$ & $\begin{array}{r}3950- \\
8120\end{array}$ & $\begin{array}{r}5220- \\
8000\end{array}$ & \\
\hline & IQR & $5780-7280$ & $6115-8320$ & $\begin{array}{l}5780- \\
6790\end{array}$ & $\begin{array}{r}4520- \\
6380\end{array}$ & $\begin{array}{r}6490- \\
7950\end{array}$ & $\begin{array}{l}5770- \\
\quad 6640\end{array}$ & $\begin{array}{r}5400- \\
6770\end{array}$ & $\begin{array}{r}6185- \\
7050\end{array}$ & \\
\hline \multirow[t]{3}{*}{ As } & Median & 0.6 & 0.6 & 0.6 & 0.6 & 0.6 & 0.8 & 0.7 & 0.7 & \multirow[t]{3}{*}{0.158} \\
\hline & Range & $0.1-3.8$ & $0.3-3.8$ & $0.1-1.9$ & $0.3-1.4$ & $0.4-1.9$ & $0.4-1.3$ & $0.1-1.6$ & $0.1-1.4$ & \\
\hline & IQR & $0.5-0.9$ & $0.4-0.9$ & $0.4-0.7$ & $0.5-0.6$ & $0.5-1.1$ & $0.5-1.2$ & $0.5-1$ & $0.5-1.1$ & \\
\hline \multirow[t]{3}{*}{$\mathrm{Se}^{c}$} & Median & 64 & 60 & 57 & 61 & 60 & 73 & 57 & & \multirow[t]{3}{*}{$0.0001^{c}$} \\
\hline & Range & $36-233$ & $39-97$ & $36-91$ & 46-108 & $43-91$ & $60-233$ & $40-127$ & 50-104 & \\
\hline & IQR & $54-73$ & $52-70$ & $47-65$ & $52-74$ & $56-69$ & $67-99$ & $49-70$ & $67-82$ & \\
\hline
\end{tabular}


$\left.\mathrm{L}^{-1}\right)$. Cord blood copper and zinc median levels were found to be $705 \mu \mathrm{g} \mathrm{L} \mathrm{L}^{-1}$ and $2600 \mu \mathrm{g} \mathrm{L} \mathrm{L}^{-1}$, respectively.

\section{Correlation between maternal and cord blood samples}

The results of Spearman's correlation coefficient, used to assess the correlation for each element between paired maternal and cord blood, show that there was a significant correlation for $\mathrm{Hg}$, $\mathrm{Pb}, \mathrm{Mn}$ and $\mathrm{Co}$ (summarized in Table 5). The r-square value for the correlation coefficients indicates the percentage of the relation between maternal and cord blood (e.g. $\mathrm{Hg}-$ in $65.6 \%$ of cases cord blood levels increased when maternal blood levels increased).

\section{Discussion}

It is understood that human exposure to toxicants, starting at pre-conception and during the prenatal stage, has implications for pregnancy outcome as well as for children's health, morbidity and mortality occurring later in their life. ${ }^{28}$ This study quantified the levels of toxic and essential elements in 155 delivering women residing in seven selected sites of São Paulo State in Brazil.

Overall, the study found very low concentrations of toxic metals in whole blood of delivering women in all sites, but site differences were evident. These findings could indicate either low environmental contamination in São Paulo State in Brazil, and/

Table 4 Concentration of $\mathrm{Cd}, \mathrm{Hg}, \mathrm{Pb}, \mathrm{Mn}, \mathrm{Co}, \mathrm{Cu}, \mathrm{Zn}$, As, Se and $\mathrm{Mo}$ in cord blood $\left(\mu \mathrm{g} \mathrm{L}^{-1}\right)$ for Rural 1 site $^{a}$

\begin{tabular}{|c|c|c|c|}
\hline $\begin{array}{l}\text { Elements } \\
\left(\mu \mathrm{g} \mathrm{L}^{-1}\right)\end{array}$ & Statistics & $\begin{array}{l}\text { Rural } 1 \text { (maternal) } \\
\mathrm{N}=36\end{array}$ & $\begin{array}{l}\text { Rural 1 (cord) } \\
\mathrm{N}=32\end{array}$ \\
\hline \multirow[t]{3}{*}{$\mathrm{Cd}$} & Median & 0.09 & 0.01 \\
\hline & Range & $0.01-0.58$ & $0.01-0.10$ \\
\hline & IQR & $0.07-0.13$ & $0.01-0.01$ \\
\hline \multirow[t]{3}{*}{$\mathrm{Hg}^{c}$} & Median & 0.60 & 1.07 \\
\hline & Range & $0.06-4.35$ & $0.44-8.26$ \\
\hline & IQR & $0.38-0.97$ & $0.75-1.79$ \\
\hline \multirow[t]{3}{*}{$\mathrm{Pb}^{c}$} & Median & 16.2 & 12.87 \\
\hline & Range & $3.5-57.7$ & $7.45-26.40$ \\
\hline & IRQ & $12.2-20.4$ & $10.50-15.75$ \\
\hline \multirow[t]{3}{*}{$\mathrm{Mn}^{b}$} & Median & 16.7 & 36.62 \\
\hline & Range & $7.0-39.7$ & $22.46-66.07$ \\
\hline & IQR & $13.2-21.6$ & $30.42-46.74$ \\
\hline \multirow[t]{3}{*}{$\mathrm{Co}^{b}$} & Median & 0.25 & 0.22 \\
\hline & Range & $0.06-1.1$ & $0.08-0.93$ \\
\hline & IQR & $0.17-0.40$ & $0.17-0.34$ \\
\hline \multirow[t]{3}{*}{$\mathrm{Cu}^{c}$} & Median (SD) & 1735 & 705 \\
\hline & Range & $610-3070$ & $570-1400$ \\
\hline & IQR & $1540-1930$ & $660-820$ \\
\hline \multirow[t]{3}{*}{$\mathrm{Zn}$} & Median & 6420 & 2600 \\
\hline & Range & $2850-10100$ & $1800-6370$ \\
\hline & IQR & $5780-7280$ & $2340-2940$ \\
\hline \multirow[t]{3}{*}{ As } & Median & 0.6 & 0.97 \\
\hline & Range & $0.1-3.8$ & $0.44-4.50$ \\
\hline & IQR & $0.5-0.9$ & $0.68-1.44$ \\
\hline \multirow[t]{3}{*}{$\mathrm{Se}$} & Median & 64 & 76.48 \\
\hline & Range & $36-233$ & $52.76-152.25$ \\
\hline & IQR & $54-73$ & $66.35-82.57$ \\
\hline \multirow[t]{3}{*}{ Mo } & Median & 0.53 & 0.51 \\
\hline & Range & $0.22-1.48$ & $0.22-1.42$ \\
\hline & IQR & $0.43-0.76$ & $0.41-0.73$ \\
\hline
\end{tabular}

${ }^{a} \mathrm{IQR}=$ inter-quartile range $(25-75) .{ }^{b}$ Statistically significant differences $(\mathrm{p}<0.05) .{ }^{c}$ Statistically significant differences $(\mathrm{p}<0.001)$. or a lack of direct contact between pregnant women and pollutants, possibly due to the general public awareness implemented by public health practitioners.

People may be exposed to potentially harmful chemical, physical and biological agents in air, food, water and/or soil. However, exposure does not result only from the presence of a harmful agent in the environment; the key concepts in the definition of exposure are contact and route of exposure. ${ }^{29}$ The cord blood levels indicate the foetal exposure to different metals during the neonatal stage. These values are dependent on the permeability of the placental membrane to specific metals. The placental membrane is the contact surface separating maternal levels of toxic elements from foetal exposure. Our results show that in the case of two toxic heavy metals (viz. $\mathrm{Pb}$ and $\mathrm{Hg}$ ) there is a positive correlation between the maternal and foetal environments.

The results indicated significant statistical differences in maternal blood levels in different sites for $\mathrm{Cd}, \mathrm{Mn}, \mathrm{Cu}, \mathrm{Zn}, \mathrm{Se}$ and Mo. We confirmed a limited transfer $(10 \%)$ of $\mathrm{Cd}$ from mother to foetus, which is in agreement with other studies ${ }^{30,31}$ but found no correlation between levels of maternal $\mathrm{Cd}$ and smoking. However, this natural placenta protection for $\mathrm{Cd}$ transfer is applicable only in the foetus and the newborn stages. As the main $\mathrm{Cd}$ exposure sources in children are food, environmental tobacco smoke and house dust, $\mathrm{Cd}$ will be stored in the liver and kidney and exert its chronic toxicity mainly to renal and neurological systems over a period of time. ${ }^{32}$ In addition, increased absorption of $\mathrm{Cd}$ can also occur in conjunction with low iron stores in pregnant women, suggesting a common mechanism of uptake for both metals. ${ }^{33-35}$

In our study, $\mathrm{Hg}$ was detected in $100 \%$ of blood samples. Overall concentrations were found to be lower than those reported recently from South Africa where median $\mathrm{Hg}$ concentration in blood of women residing along the Atlantic Ocean and Indian Ocean was found to be $1.78 \mu \mathrm{g} \mathrm{L}^{-1}$ and $0.93 \mu \mathrm{g} \mathrm{L}^{-1}$, respectively. ${ }^{36}$ Nevertheless, an enhanced permeability of the placenta for $\mathrm{Hg}$ was also detected, and the $\mathrm{Hg}$ ratio of cord blood to maternal blood (measured only in Rural 1 site in the present study) was 1.79 , which is similar to the ratios reported by other investigators. ${ }^{31,37}$ Although the majority of studies associate elevated concentrations of $\mathrm{Hg}$ with the high consumption of contaminated fish, in this study no confounding effect was found. These findings are similar to those of the recent South African study. ${ }^{36}$ In both Brazil and South Africa, a very low consumption of fish was reported in the study populations, suggesting a different source of $\mathrm{Hg}$ exposure.

Table 5 Spearman's correlations and p-value for the maternal and cord blood values for analysed substances

\begin{tabular}{lll}
\hline Tested correlation & Correlation coefficient & p value \\
\hline MoM vs. MoC & 0.32 & 0.097 \\
CdM vs. CdC & 0.072 & 0.715 \\
$\mathrm{HgM}$ vs. $\mathrm{HgC}$ & 0.82 & 0.0001 \\
$\mathrm{PbM}$ vs. PbC & 0.77 & 0.0001 \\
$\mathrm{MnM}$ vs. MnC & 0.37 & 0.05 \\
$\mathrm{CoM}$ vs. CoC & 0.59 & 0.0001 \\
$\mathrm{CuM}$ vs. CuC & -0.27 & 0.16 \\
$\mathrm{ZnM}$ vs. ZnC & 0.15 & 0.46 \\
SeM vs. SeC & 0.18 & 0.36 \\
AsM $v s$. AsC & 0.33 & 0.09 \\
\hline
\end{tabular}


Maternal and cord blood levels of $\mathrm{Pb}$ were found to be similar - and low - but research suggests that there is no safe level of $\mathrm{Pb}$, with endogenous exposure occurring mostly during the critical and sensitive stages of organ development in the foetus, the nursing infant and the young child.

Levels of the essential metals $\mathrm{Cu}$ and $\mathrm{Zn}$ were found to be within normal ranges, but Se levels were low. ${ }^{38,39}$ This finding is in agreement with another Brazilian study by Pinheiro et al., who found lower Se levels in pregnant women, when compared to non-pregnant women in the Amazonian population. ${ }^{18}$ This outcome may indicate a low dietary intake of Se in the study group, as well as high Se consumption by the foetus during pregnancy. This absorption of Se is thought to be one of the protective mechanisms against the cytotoxic effects of $\mathrm{Hg}$.

Concentrations of maternal blood $\mathrm{Mn}$ were found to be close to the upper accepted normal levels of $14 \mu \mathrm{g} \mathrm{L}^{-1} \cdot{ }^{40} \mathrm{Mn}$ is an essential trace element, with both deficiency and excess being toxic. In agreement with other studies, the Mn levels observed in cord blood were found to be higher than the respective maternal concentrations. This is thought to be due to the natural compromising process mechanism observed for the elimination of Mn by the foetus. ${ }^{41}$ In this study, maternal age was also found to be a confounding factor for Mn levels, with older women having higher levels.

A review of the scientific literature has shown an established association between toxic metal exposures and adverse pregnancy outcomes, but the full impact of exposure to low levels of metals during pregnancy is still not fully understood and further investigations are required. ${ }^{42}$ In addition, there is limited knowledge about the synergistic effects of simultaneous exposures to multiple toxicants. Similarly, an investigation into the potential interactions between exposures to pesticides and to metals is indicated, to further elucidate mechanisms of action.

To the best of our knowledge, this pilot study is the first performed in Brazil that measured a broad spectrum of pollutants in delivering mothers residing in different locations within São Paulo State.

The data obtained will constitute baseline information for similar studies to be conducted in other geographical regions within Brazil, as well as in other regions in the southern hemisphere.

It is also important to point out that this study involved a multidisciplinary team of research scientists and created the ideal platform for building research capacity in Brazil and elsewhere, and it is anticipated to lead to future collaborative research opportunities.

\section{Acknowledgements}

The authors are indebted to the University of Tromsø, Norway; the University of Aarhus, Denmark; the Arctic Monitoring and Assessment Programme (AMAP), Oslo, Norway; and the Nordic Council of Ministers, Copenhagen, Denmark for the financial support of this study. We deeply thank all the participants who kindly participated in this survey and staff at the seven study sites, who enrolled patients for this study. We also thank Maria Aparecida Mourão Brazil, Adriano Dias, and Hélio Rubens Nunes from GAP-Research Support Center, for statistical support. The first author (C. R.) is a recipient of a doctoral PDEE fellowship from the Brazilian Federal Agency for Graduate Studies (CAPES, Ministry of Education).

\section{References}

1 L. Jarup, Br. Med. Bull., 2003, 68, 167-182.

2 A. Mathee, H. Röllin, Y. von Schirnding, J. Levin and I. Naik, Environ. Res., 2006, 100, 319-322.

3 J. O. Odland, E. Nieboer, N. Romanova and Y. Thomassen, Int. J. Circumpolar Health, 2004, 63, 169-187.

4 E. Nieboer, Y. Thomassen, N. Romanova, A. Nikonov, J. O. Odland and V. Chaschin, J. Environ. Monit., 2007, 9, 695-700.

5 G. A. Koyashiki, M. M. Paoliello, T. Matsuo, M. M. de Oliveira, L. Mezzaroba, F. Carvalho Mde, A. M. Sakuma, C. Turini, M. T. Vannuchi and C. S. Barbosa, Environ. Res., 2010, 110, 265-271.

6 J. O. Odland, N. Romanova, G. Sand, Y. Thomassen, B. Salbu, E. Lund, E. Nieboer, in Environmental Biomonitoring, Exposure Assessment and Specimen Banking, ed. ACS Publications, Exposure Assessment and Specimen Banking, American Chemical Society, Washington 1997, pp. 135-150.

7 J. C. Van Oostdam, E. Dewailly, A. Gilman, J. C. Hansen, J. O. Odland, V. Chashchin, J. Berner, J. Butler-Walker, B. J. Lagerkvist, K. Olafsdottir, L. Soininen, P. Bjerregard, V. Klopov and J. P. Weber, Sci. Total Environ., 2004, 330, 55-70.

8 B. Deutch, J. Dyerberg, H. S. Pedersen, E. Aschlund and J. C. Hansen, Sci. Total Environ., 2007, 384, 106-119.

9 E. Eik Anda, E. Nieboer, A. A. Dudarev, T. M. Sandanger and J. O. Odland, J. Environ. Monit., 2007, 9, 884-893.

10 CETESB (2001). Relatório Tecnico da CETESB- Companhia de Tecnologia e Saneamento Ambiental, PROCOP - Programa de Controle da Poluiçao. S. d. M. Ambiente. Sao Paulo Brazil.

11 M. M. Paoliello, E. M. De Capitani, F. G. da Cunha, T. Matsuo, F. Carvalho Mde, A. Sakuma and B. R. Figueiredo, Environ. Res, 2002, 88, 120-128.

12 C. S. Freitas, M. Silva, A. Sakuma, M. C. Duran, M. F. Carvalho, P. Tiglea, E. M. De Capitani, T. Buschinelli and A. Braga, Epidemiology, 2003, 14.

13 F. M. Carvalho, M. L. Barreto, A. M. Silvany-Neto, H. A. Waldron and T. M. Tavares, Sci. Total Environ., 1984, 35, 71-84.

14 F. M. Carvalho, T. M. Tavares, A. M. Silvany-Neto, M. E. Lima and F. Alt, Environ. Res., 1986, 40, 437-449.

15 F. M. Carvalho, A. M. Silvany-Neto, A. C. Barbosa, C. R. Cotrim and T. M. Tavares, Environ. Res., 1995, 71, 11-15.

16 A. Mathee, Y. E. von Schirnding, J. Levin, A. Ismail, R. Huntley and A. Cantrell, Environ. Res., 2002, 90, 181-184.

17 A. C. Barbosa, S. R. Silva and J. G. Dorea, Arch. Environ. Contam. Toxicol., 1998, 34, 100-105.

18 M. C. Pinheiro, R. C. Muller, J. E. Sarkis, J. L. Vieira, T. Oikawa, M. S. Gomes, G. A. Guimaraes, J. L. do Nascimento and L. C. Silveira, Sci. Total Environ., 2005, 349, 284-288.

19 F. L. Barbieri, A. Cournil and J. Gardon, Int. J. Environ. Health Res., 2009, 19, 267-277.

20 R. C. Oliveira, J. G. Dorea, J. V. Bernardi, W. R. Bastos, R. Almeida and A. G. Manzatto, Ann. Hum. Biol., 2010.

21 A. F. Castoldi, T. Coccini and L. Manzo, Rev. Environ. Health, 2003, 18, 19-31.

22 W. Jedrychowski, E. Flak, E. Mroz, A. Pac, R. Jacek, E. SochackaTatara, J. Spengler, V. Rauh and F. Perera, Ann. Nutr. Metab., 2008, 52, 8-16.

23 R. C. Marques, J. G. Dorea, M. F. Fonseca, W. R. Bastos and O. Malm, Eur. J. Pediatr., 2007, 166, 935-941.

24 M. Vahter, M. Berglund, A. Akesson and C. Liden, Environ. Res., 2002, 88, 145-155.

25 A. Vaktskjold, L. V. Talykova, V. P. Chashchin, E. Nieboer, Y. Thomassen and J. O. Odland, Scand. J. Work Environ. Health, 2006, 32, 41-50.

26 T. M. Sandanger, M. Sinotte, P. Dumas, M. Marchand, C. D. Sandau, D. Pereg, S. Berube, J. Brisson and P. Ayotte, Environ. Health Perspect., 2007, 115, 1429-1434.

27 Stata10, in College Station TX, ed. StataCorpLP, 2007.

28 P. Grandjean, P. Weihe and J. B. Nielsen, Clin. Chem., 1994, 40, 1395-1400.229.

29 M. Berglund, C. Elinder and L. Jarup, ed. WHO/SDE/OEHO.1.3, 2001. 
30 K. Osman, A. Akesson, M. Berglund, K. Bremme, A. Schutz, K. Ask and M. Vahter, Clin. Biochem., 2000, 33, 131-138.

31 C. V. Rudge, H. B. Röllin, C. M. Nogueira, Y. Thomassen, M. C. Rudge and J. O. Odland, J. Environ. Monit., 2009, 11, 13221330.

32 F. P. Perera, V. Rauh, R. M. Whyatt, D. Tang, W. Y. Tsai, J. T. Bernert, Y. H. Tu, H. Andrews, D. B. Barr, D. E. Camann, D. Diaz, J. Dietrich, A. Reyes and P. L. Kinney, NeuroToxicology, 2005, 26, 573-587.

33 A. Akesson, M. Berglund, A. Schutz, P. Bjellerup, K. Bremme and M. Vahter, Am. J. Public Health, 2002, 92, 284-287.

34 M. Berglund, B. Lind, E. Lannero and M. Vahter, Arch. Environ. Contam. Toxicol., 1994, 27, 281-287.

35 J. A. Staessen, R. R. Lauwerys, J. P. Buchet, C. J. Bulpitt, D. Rondia, Y. Vanrenterghem and A. Amery, N. Engl. J. Med., 1992, 327, 151156.
36 H. B. Röllin, C. V. Rudge, Y. Thomassen, A. Mathee and J. O. Odland, J. Environ. Monit., 2009, 11, 618-627.

37 M. Vahter, A. Akesson, B. Lind, U. Bjors, A. Schutz and M. Berglund, Environ. Res., 2000, 84, 186-194.

38 B. L. Gulson, M. James, A. M. Giblin, A. Sheehan and P. Mitchell, Sci. Total Environ., 1997, 205, 271-275.

39 B. L. Gulson, C. W. Jameson, K. R. Mahaffey, K. J. Mizon, N. Patison, A. J. Law, M. J. Korsch and M. A. Salter, Environ. Health Perspect., 1998, 106, 667-674.

40 ATSDR, Toxicological Profile for Manganese, Agency for Toxic Substances and Disease Registry, Atlanta, 2000.

41 M. Aschner, B. Lukey and A. Tremblay, NeuroToxicology, 2006, 27, 733-736.

42 K. Polanska, W. Hanke, J. Gromadzinska, D. Ligocka, E. Gulczynska, W. Sobala and W. Wasowicz, Int. J. Occup. Med. Environ. Health, 2009, 22, 383-391. 